\title{
Lipid-coated iron oxide nanoparticles for dual-modal imaging of hepatocellular carcinoma
}

\author{
This article was published in the following Dove Press journal: \\ International Journal of Nanomedicine \\ 14 March 2017 \\ Number of times this article has been viewed
}

\section{Jinying Liang ${ }^{1-3}$ \\ Xinxin Zhang ${ }^{2}$ \\ Yunqiu Miao ${ }^{2}$ \\ Juan $\mathrm{Li}^{\prime}$ \\ Yong $\mathrm{Gan}^{2}$}

'Department of Pharmaceutics, China Pharmaceutical University, Nanjing, People's Republic of China; ${ }^{2}$ Shanghai Institute of Materia Medica, Chinese Academy of Sciences, Shanghai, People's Republic of China; ${ }^{3}$ School of Pharmacy, Xinxiang Medical University, Xinxiang, People's Republic of China

Correspondence: Juan Li Department of Pharmaceutics, China Pharmaceutical University, 24 Tongjiaxiang, Nanjing 210009 , People's Republic of China

Tel $+86258327 \quad$ I287

Fax +86 258327 I766

Email lijuancpu@।63.com

Xinxin Zhang

Shanghai Institute of Materia Medica,

Chinese Academy of Sciences,

50I Haike Road, Shanghai 20I203,

People's Republic of China

Tel +86 2I $2023 \quad 1000$ ext I 424

Fax +862120231000 ext 1425

Email xinxinzhang@simm.ac.cn

\begin{abstract}
The development of noninvasive imaging techniques for the accurate diagnosis of progressive hepatocellular carcinoma (HCC) is of great clinical significance and has always been desired. Herein, a hepatocellular carcinoma cell-targeting fluorescent magnetic nanoparticle (NP) was obtained by conjugating near-infrared fluorescence to the surface of $\mathrm{Fe}_{3} \mathrm{O}_{4}\left(\mathrm{NIRF}-\mathrm{Fe}_{3} \mathrm{O}_{4}\right)$ NPs, followed by coating the lipids consisting of tumoral hepatocytes-targeting polymer (Gal$\left.\mathrm{P}_{123}\right)$. This magnetic NP (GPC@NIRF- $\left.\mathrm{Fe}_{3} \mathrm{O}_{4}\right)$ with superparamagnetic behavior showed high stability and safety in physiological conditions. In addition, GPC@NIRF-Fe $\mathrm{O}_{4}$ achieved more specific uptake of human liver cancer cells than free $\mathrm{Fe}_{3} \mathrm{O}_{4}$ NPs. Importantly, with superparamagnetic iron oxide and strong NIR absorbance, GPC@NIRF-Fe $\mathrm{O}_{4} \mathrm{NPs}$ demonstrate prominent tumor-contrasted imaging performance both on fluorescent and $\mathrm{T}_{2}$-weighted magnetic resonance (MR) imaging modalities in a living body. The relative MR signal enhancement of GPC@NIRF$\mathrm{Fe}_{3} \mathrm{O}_{4}$ NPs achieved 5.4-fold improvement compared with NIR-Fe $\mathrm{O}_{4}$ NPs. Therefore, GPC@, NIRF-Fe $\mathrm{O}_{4}$ NPs may be potentially used as a candidate for dual-modal imaging of tumors with information covalidated and directly compared by combining fluorescence and MR imaging.

Keywords: dual-imaging, magnetic resonance imaging, hepatocellular carcinoma, tumortargeting
\end{abstract}

\section{Introduction}

Hepatocellular carcinoma (HCC) is the third highest cause of mortality among all malignant tumors in the world. ${ }^{1-3}$ Accurate diagnosis of $\mathrm{HCC}$ is crucial for optimizing treatment outcomes. ${ }^{4}$ Diagnostic imaging technology, including ultrasound (US), computed tomography (CT), and positron emission computed tomography (PET), has become an active area of research and has been playing a key role in $\mathrm{HCC}$ diagnosis. ${ }^{5-8}$ Despite the diversity of bio-imaging techniques, several technical problems have yet to be solved, such as weak penetrability, low sensitivity, and insufficient spatial or temporal resolution, which hinder accurate diagnosis. ${ }^{9,10}$

Magnetic resonance imaging (MRI), with the advantages of noninvasive, multiparametric imaging and deep soft-tissue penetration, has become a powerful technique in cancer diagnosis. ${ }^{11-13}$ Superparamagnetic iron oxide nanoparticles (NPs), a kind of powerful T2 contrast agent, are commonly used as magnetic vectors for MRI. Compared with gadolinium-based MRI contrast agents, including Magnevist ${ }^{\circledR}$ (Gd-DTPA; Bayer Schering Pharma, Berlin, Germany) and Multihance ${ }^{\circledR}$ (Gd-BOPTA; Bracco Diagnostics Inc., Princeton, NJ, USA), ${ }^{14,15}$ superparamagnetic iron oxide NPs have been intensively investigated as promising MRI probes because of their biocompatibility and safety profiles as well as suitable magnetic properties. ${ }^{16-18}$ However, limitations such as low sensitivity have hindered the further application of MRI as the sole methodology in the diagnosis 
of HCC. ${ }^{19-21}$ To overcome the shortcomings, multimodal imaging techniques combining complementary advantages of different imaging modalities have attracted significant attention. For example, CT/MR imaging is obtained by multimodal contrast agents based on $\mathrm{Au}$ and $\mathrm{Fe}_{3} \mathrm{O}_{4}$ NPs to get more information of tumor localization, ${ }^{22-24}$ while Au shell coated on the surface of $\mathrm{Fe}_{3} \mathrm{O}_{4}$ NPs may also result in the reduction of MRI contrast signal. Moreover, PET/MRI has been used clinically worldwide because PET is highly concentration-sensitive while supplying low resolution and MRI provides anatomic information in submillimeter range with high resolution. ${ }^{25,26}$ Nevertheless, there are drawbacks; for instance, PET-MRI systems can suffer from unwanted interference between PET radiofrequencies and MRI magnetic fields.

Lately, along with the development of versatile fluorescent probes, especially near-infrared fluorescent probes, fluorescence imaging (FI) is becoming a promising tool to noninvasively resolve three-dimensional spatial distribution of fluorescent probes associated with molecular and cellular function. ${ }^{27}$ Compared with other modalities, FI has several advantages, such as high sensitivity and specificity, operational simplicity, safety, and cost effectiveness, ${ }^{28,29}$ though limited depth perception. Thus, the combination of FI and MRI into a single nanostructure can offer robust imaging capabilities with the prospect of improved detection accuracy in clinical diagnosis. ${ }^{29-31}$ To date, there is no commercial probe available in the market with MRI/FI dual-modal capabilities. In the present study, a multifunctional nanoplatform consist of galactosyl conjugated $\mathrm{P}_{123}\left(\mathrm{Gal}-\mathrm{P}_{123}\right)$-modified IR783- $\mathrm{Fe}_{3} \mathrm{O}_{4}$ (GPC@IR783- $\mathrm{Fe}_{3} \mathrm{O}_{4}$ ) NPs was designed for dual-modal fluorescence and MR imaging of tumors. $\mathrm{Fe}_{3} \mathrm{O}_{4}$ NPs were first labeled with IR-783 and then encapsulated in a lipid shell modified with hepatocellular carcinomatargeting polymer (Figure 1). Gal- $\mathrm{P}_{123}$ was an HCC targeting material that was synthesized in our previous study. ${ }^{32,33} \mathrm{We}$ hypothesize that Gal-P ${ }_{123}$ conjugated with fluorescence-MRI nanoparticle systems may enhance the resolution of targeting sites and supply reliable covalidation diagnosis of HCC. The formed GPC@IR783-Fe $\mathrm{O}_{4}$ NPs were characterized, and then their cytocompatibility and in vivo biocompatibility were evaluated. To demonstrate the diagnostic potential of these NPs, specific cellular uptake was examined by flow cytometry and confocal laser scanning microscopy (CLSM), and in addition, dual-modal fluorescence-MR imaging of tumor was evaluated in Huh-7 tumor-bearing mice.

\section{Materials and methods Materials}

$\mathrm{Fe}_{3} \mathrm{O}_{4}$ NPs were supplied by Shanghai Jiao Tong University (Shanghai, People's Republic of China). Gal-P ${ }_{123}$ was obtained in our laboratory. Lipoid phosphatidylcholine (PC) was supplied by Lipoid GmbH (Ludwigshafen, Germany). 3-(4,5-Dimethylthiazol-2-yl)-2,5-diphenyltetrazolium bromide (MTT) was from Sigma-Aldrich (St Louis, MO, USA). All chemicals were reagent grade and used without further purification or modification.

SK-hep-1 cells were obtained from Shanghai Cell Bank, Chinese Academy of Sciences (CAS, Shanghai, People's Republic of China), and maintained in RPMI 1640 supplemented with $10 \% \mathrm{FBS}$, and $1 \%$ penicillin/streptomycin (Sigma-Aldrich). LO2 cells were provided by Shanghai Cell Bank, CAS, and grown in DMEM supplemented with 10\% FBS (Thermo Fisher Scientific, Waltham, MA, USA) and other supplements mentioned above. All cells were kept at $37^{\circ} \mathrm{C}$ in a humidified and $5 \% \mathrm{CO}_{2}$ incubator.

\section{Animals and tumor xenograft models}

BALB/c nude mice (18-22 g, đ) were provided by Shanghai Laboratory Animal Center, CAS. These animals were maintained under the animal care facility for acclimatization

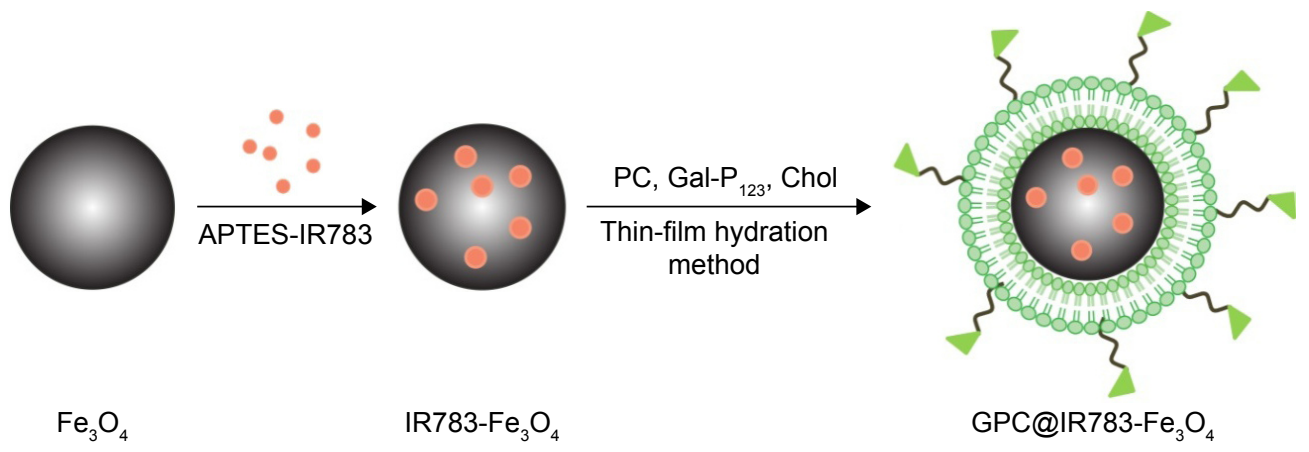

Figure I Schematic illustration of the construction of GPC@IR783- $-\mathrm{Fe}_{3} \mathrm{O}_{4}$ nanoparticles (NPs).

Abbreviations: Gal- $\mathrm{P}_{123}$, galactosyl conjugated pluronic $\mathrm{P}_{123}$; Chol, cholesterol; APTES, aminopropyltriethoxysilane; PC, phosphatidylcholine; GPC, galactosyl conjugated pluronic $\mathrm{P}_{123}$ /phosphatidylcholine. 
at least 5 days prior to the experiment. Animal experiments were executed according to the protocol approved by the Institutional Animal Care and Use Committee (IACUC) of Shanghai Institute of Materia Medica, CAS. To induce solid tumor, $1 \mathrm{~mL}$ of hepatic carcinoma cells (Huh- $7,1 \times 10^{8}$ cells in $1 \mathrm{~mL}$ PBS) were inoculated subcutaneously in the right armpit region of the animals.

\section{Preparation of multifunctional $\mathrm{Fe}_{3} \mathrm{O}_{4} \mathrm{NPs}$} Prior to the preparation of multifunctional $\mathrm{Fe}_{3} \mathrm{O}_{4} \mathrm{NPs}$, IR-783 (or Rhodamine isothiocyanate [RITC]) was labeled to $\mathrm{Fe}_{3} \mathrm{O}_{4}$ NPs. First, RITC or IR-783 was covalently bound with 3-aminopropyltriethoxysilane in ethanol, and then $10 \mathrm{mg}$ of $\mathrm{Fe}_{3} \mathrm{O}_{4}$ NPs were added to form the conjugation. The reaction was carried out for $8 \mathrm{~h}$, and the solution was centrifuged, washed with ethanol, and ultrasonicated three times to remove the unconjugated IR-783 (or RITC) and 3-aminopropyltriethoxysilane. ${ }^{34}$ Particles were collected and stored in PBS. Then, Gal- $\mathrm{P}_{123}$ modified IR783-Fe $\mathrm{O}_{4}$ (GPC@ IR783- $\left.\mathrm{Fe}_{3} \mathrm{O}_{4}\right)$ NPs were prepared by the thin-film dispersion method. PC, Gal- ${ }_{123}$, and Chol (Gal-P ${ }_{123}, 3.5 \mathrm{mg}$; PC, $5.5 \mathrm{mg}$; and Chol, $0.9 \mathrm{mg}$ ) were dissolved in chloroform in a round flask and evaporated to form a thin film under reduced pressure. Finally, the film was dispersed in IR-783-labeled $\mathrm{Fe}_{3} \mathrm{O}_{4}$ NPs solution by gentle shaking at $37^{\circ} \mathrm{C}$. This was followed by extruding four times through a $200 \mathrm{~nm}$-pore polycarbonate membrane with an Avestin Emulsi Flex-C5 high pressure extruder (Ottawa, ON, Canada). PC modified IR783- $\mathrm{Fe}_{3} \mathrm{O}_{4}$ (PC@IR783- $-\mathrm{Fe}_{3} \mathrm{O}_{4}$ ) NPs were formulated using the same method, except that the shell consisted of PC and Chol (PC, $9 \mathrm{mg}$; Chol, $0.9 \mathrm{mg}$ ). Gel-filtration chromatography was used for purification of PC@IR783- $\mathrm{Fe}_{3} \mathrm{O}_{4}$ and GPC@IR783- $-\mathrm{Fe}_{3} \mathrm{O}_{4}$ from the excess of uncoated lipid.

\section{Characterization of $\mathrm{Fe}_{3} \mathrm{O}_{4} \mathrm{NPs}$}

The mean diameter and zeta potential of NPs in water were monitored by a Malvern Zetasizer Nano ZS analyzer (Malvern Instruments Ltd., Worcestershire, UK). The morphology and nanostructure of IR783- $\mathrm{Fe}_{3} \mathrm{O}_{4}, \mathrm{PC} @$ IR783- $-\mathrm{Fe}_{3} \mathrm{O}_{4}$, and GPC@IR783- $\mathrm{Fe}_{3} \mathrm{O}_{4}$ were observed via transmission electron microscopy (TEM). TEM micrographs were obtained on JEOL-2010 TEM (JEOL Ltd., Tokyo, Japan) at an accelerating voltage of $200 \mathrm{kV}$.

\section{Vibrating sample magnetometry (VSM) analysis}

The magnetic properties of IR783- $\mathrm{Fe}_{3} \mathrm{O}_{4}, \mathrm{PC} @ \mathrm{IR} 783-\mathrm{Fe}_{3} \mathrm{O}_{4}$, and GPC@IR783-Fe $\mathrm{O}_{4}$ NPs were studied by using a VSM
(Lake Shore Cryotronics, Westerville, OH, USA) at room temperature up to $\mathrm{H}=2 \mathrm{~T}$. Saturation magnetization was obtained by extrapolating to an infinite field the experimental results obtained in the high field range, where magnetization linearly increases with $1 / \mathrm{H}$.

\section{In vitro cytotoxicity study}

The cell viability of IR-783-labeled iron oxide NPs on normal cell lines (LO2) was evaluated by using the standard MTT assay. LO2 cells $\left(1 \times 10^{4}\right.$ cells per well) were seeded in 96-well culture plates. After being cultured for $24 \mathrm{~h}$, the cells were exposed to NPs with different concentrations for $24 \mathrm{~h}$, after which $20 \mu \mathrm{L} 5 \mathrm{mg} / \mathrm{mL}$ MTT (Sigma) solution was added. After $4 \mathrm{~h}$ of incubation, the medium was removed, and the cells were mixed with $150 \mu \mathrm{L}$ of dimethyl sulfoxide. The absorbance of solutions was measured at a test wavelength of $490 \mathrm{~nm}$ by a microplate reader. Relative cell viability $(R)$ was calculated as follows. $R(\%)=A_{\text {test }} / A_{\text {control }} \times 100 \%$, where $A_{\text {test }}$ and $A_{\text {control }}$ were the absorbance of the cells treated with the test solutions and blank culture medium (FBS free) as a negative control, respectively.

\section{Cellular uptake of RITC-labeled $\mathrm{Fe}_{3} \mathrm{O}_{4} \mathrm{NPs}$}

Huh-7 cells $\left(1 \times 10^{5}\right.$ cells per well $)$ were seeded in $24-w e l l$ plates and cultured at $37^{\circ} \mathrm{C}$ for $24 \mathrm{~h}$. The medium was replaced with fresh medium; meanwhile, RITC-labeled iron oxide NPs $(100 \mu \mathrm{g} / \mathrm{mL} \mathrm{Fe} /$ well $)$ were added in the culture medium and incubated for $2 \mathrm{~h}$ at $37^{\circ} \mathrm{C}$. Next, the cells were washed three times with ice-cold PBS and fixed with $4 \%$ paraformaldehyde for $15 \mathrm{~min}$, and then washed three times with PBS. The nuclei were stained with 4',6-diamidino2-phenylindole for $10 \mathrm{~min}$ and observed by CLSM.

Flow cytometry was also used to evaluate the cellular uptake of RITC-labeled $\mathrm{Fe}_{3} \mathrm{O}_{4}$ NPs $(100 \mu \mathrm{g} / \mathrm{mL} \mathrm{Fe} /$ well $)$. Huh-7 cells were seeded at $1 \times 10^{5}$ cells per well for $24 \mathrm{~h}$ at $37^{\circ} \mathrm{C}$ prior to the study. The cells were then incubated in medium containing RITC-labeled NPs. After $2 \mathrm{~h}$ of incubation, the cells were washed with PBS three times, harvested by trypsinization, and collected in PBS to quantify fluorescent signals of RITC.

\section{In vivo bio-fluorescence imaging}

Tumor-bearing mice were injected via the tail vein at a dose of $2 \mathrm{mg}$ Fe per $\mathrm{kg}$ of mouse body weight. A noninvasive near-infrared optical imaging system was used to observe distribution and tumor accumulation of IR-783-labeled iron oxide NPs at 1, 3, and $6 \mathrm{~h}$ postinjection. Visualization was 
observed at excitation of $730 \mathrm{~nm}$ and emission of $790 \mathrm{~nm}$. Tumors as well as internal organs (heart, liver, spleen, lung, and kidney) were removed at $6 \mathrm{~h}$ postinjection and analyzed directly on the fluorescence imager.

\section{In vivo $M R I$ imaging}

To investigate the iron oxide NPs' targeting potential and the MRI sensitivity of GPC@IR783- $\mathrm{Fe}_{3} \mathrm{O}_{4}$ in vivo, MRI was performed with a 7.0T experimental MRI instrument (BioSpec 70/20 USR; Bruker, Billerica, MA, USA) on Huh-7 tumor-bearing mice. Iron oxide NPs were injected intravenously at a dose of $2 \mathrm{mg}$ Fe per $\mathrm{kg}$ of mouse body weight, and the coronal MRI images were scanned at preinjection and $6 \mathrm{~h}$ postinjection ( $\mathrm{n}=3$ per group). Imaging parameters were set as follows: repetition time (TR)/echo time $(\mathrm{TE})=2,800 / 34 \mathrm{~ms}$, field of view $=4 \times 4 \mathrm{~cm}$, and slice thickness $=1 \mathrm{~mm}$. The signal intensity (SI) of the tumors was determined using a region of interest within the defined tumor area and normalized to the SI of the muscle tissue. Relative signal enhancement (RSE) of tumor was calculated using the following equation: ${ }^{35,36}$

$$
\operatorname{RSE}(\%)=1-\frac{\mathrm{SI}_{\text {post-tumor }} / \mathrm{SI}_{\text {post-muscle }}}{\mathrm{SI}_{\text {pre-tumor }} / \mathrm{SI} \mathrm{pre-muscle}_{\text {pen }}} \times 100
$$

$\mathrm{SI}_{\text {pre }}$ and $\mathrm{SI}_{\text {post }}$ were measured at preinjection and $6 \mathrm{~h}$ after injection.

\section{Histology analysis}

Two hundred microliters of normal saline containing $0.8 \mathrm{mg}$ of IR-783-labeled iron oxide NPs was injected intravenously into the nude mice through the tail vein. The mice were anatomized after 15 days. The paraffin sections of the heart, liver, spleen, lung, and kidney were stained with hematoxylin and eosin (H\&E) and visualized by the inverted fluorescence microscope.

\section{Statistical analysis}

Statistical analysis of all data was performed via Student's $t$-test or one-way analysis of variance (ANOVA) and expressed as mean \pm SD. $P$-values less than 0.05 were considered statistically significant.

\section{Results and discussion Characterization of $\mathrm{Fe}_{3} \mathrm{O}_{4} \mathrm{NPs}$}

In this study, $\mathrm{Fe}_{3} \mathrm{O}_{4}$ was labeled with IR-783 and then encapsulated in hepatocellular carcinoma-targeting polymer. The obtained NPs are biodegradable with the combined appealing features of $\mathrm{Fe}_{3} \mathrm{O}_{4}$ and lipids. The average size and zeta potential of IR783- $\mathrm{Fe}_{3} \mathrm{O}_{4}, \mathrm{PC} @ I R 783-\mathrm{Fe}_{3} \mathrm{O}_{4}$, and GPC@ IR783- $\mathrm{Fe}_{3} \mathrm{O}_{4} \mathrm{NPs}$ were determined by dynamic light scattering (Figure 2A). The average sizes of IR783- $\mathrm{Fe}_{3} \mathrm{O}_{4}, \mathrm{PC} @ I R 783-$ $\mathrm{Fe}_{3} \mathrm{O}_{4}$, and GPC@IR783- $\mathrm{Fe}_{3} \mathrm{O}_{4}$ were $70.9 \mathrm{~nm}, 81.9 \mathrm{~nm}$, and 83.2 nm, respectively. PC@IR783- $\mathrm{Fe}_{3} \mathrm{O}_{4}$ and GPC@IR783$\mathrm{Fe}_{3} \mathrm{O}_{4}$ exhibited similar zeta potential $(\sim-12 \mathrm{mV})$, whereas IR783- $\mathrm{Fe}_{3} \mathrm{O}_{4}$ was $-30 \mathrm{mV}$. Meanwhile, the morphology of three types of NPs was detected by TEM. TEM images showed that all of the NPs possessed a regular spherical shape. Both PC@IR783- $\mathrm{Fe}_{3} \mathrm{O}_{4}$ and GPC@IR783- $\mathrm{Fe}_{3} \mathrm{O}_{4}$ NPs exhibited a core-shell structure, indicating the successful coating of a lipid layer on the surface (Figure 2B). As shown in Table S1, IR783- $\mathrm{Fe}_{3} \mathrm{O}_{4}$ NPs exhibited a much bigger size compared with PC@IR783--Fe $\mathrm{O}_{4}$ and GPC@IR783-Fe $\mathrm{O}_{4}$, implying the lipid shell acted as a dispersant to avoid possible aggregation and enhance their dispersibility. Taken together, suitable surface modification could enhance the stability of magnetic NPs in various physiological conditions and may endow $\mathrm{Fe}_{3} \mathrm{O}_{4} \mathrm{NPs}$ with more promising uses in the fields of bio-imaging.

\section{Magnetic properties}

To characterize the magnetic properties of $\mathrm{Fe}_{3} \mathrm{O}_{4} \mathrm{NPs}$ with different coatings, the magnetization curves of IR783- $\mathrm{Fe}_{3} \mathrm{O}_{4}$, PC@IR783- $\mathrm{Fe}_{3} \mathrm{O}_{4}$, and GPC@IR783- $\mathrm{Fe}_{3} \mathrm{O}_{4}$ obtained by using a VSM are shown in Figure 3. All NPs showed a smooth M-H curve at ambient temperature, and the saturation magnetization values of IR783- $\mathrm{Fe}_{3} \mathrm{O}_{4}, \mathrm{PC} @ I R 783-\mathrm{Fe}_{3} \mathrm{O}_{4}$, and GPC@ IR783- $\mathrm{Fe}_{3} \mathrm{O}_{4} \mathrm{NPs}$ were found to be $55 \mathrm{emu} / \mathrm{g}, 31 \mathrm{emu} / \mathrm{g}$, and $35 \mathrm{emu} / \mathrm{g}$, respectively. Since the shell materials do not show any significant magnetic properties, the reduction in the saturation magnetization values could be explained by decreasing the $\mathrm{Fe}_{3} \mathrm{O}_{4}$ mass fraction in the total mass of the modified NPs. ${ }^{37}$ The obtained saturation magnetization of GPC@IR783-- $\mathrm{Fe}_{3} \mathrm{O}_{4}$ NPs was lower than that of IR783- $-\mathrm{Fe}_{3} \mathrm{O}_{4}$ NPs, but it was comparable to the previously published values of magnetite NPs. ${ }^{37,38}$ Because no hysteresis or remnant magnetization was observed, the superparamagnetic behavior due to the existence of $\mathrm{Fe}_{3} \mathrm{O}_{4}$ nanocores could provide a detectable response to external magnetic field.

\section{Cellular uptake of $\mathrm{Fe}_{3} \mathrm{O}_{4} \mathrm{NPs}$ in Huh-7 cells}

To evaluate the in vitro specific cellular uptake of Gal- $\mathrm{P}_{123}$ conjugated RITC-Fe $\mathrm{O}_{4} \mathrm{NPs}$, cell imaging was performed using CLSM with Huh-7 cells, which have a high expression of asialoglycoprotein (ASGP) receptors. As shown in Figure 4A, Huh-7 cells treated with GPC@RITC-Fe $\mathrm{O}_{4}$ NPs displayed a strong fluorescence signal. In contrast, only a 
A

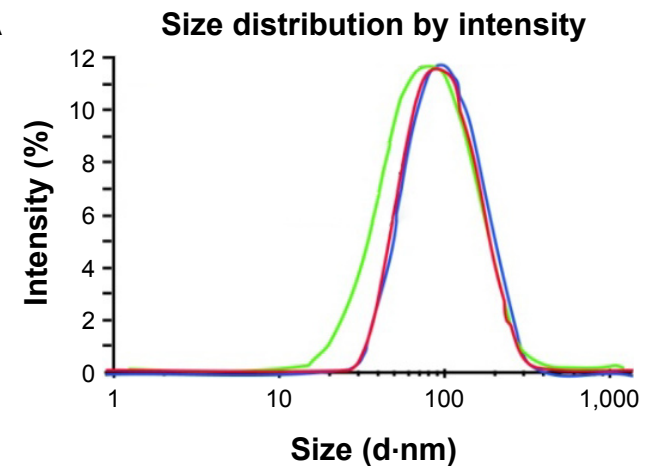

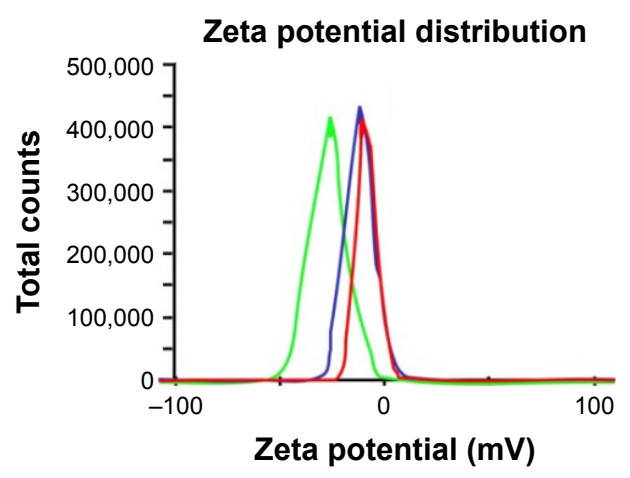

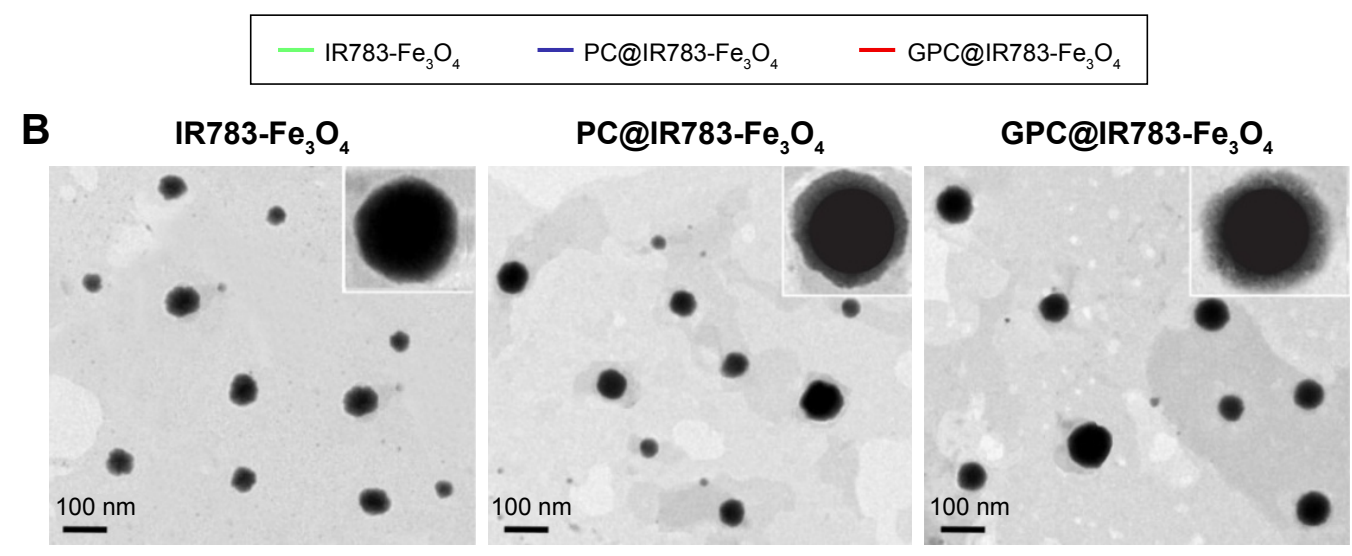

Figure 2 (A) Average size and zeta potential of IR783- $\mathrm{Fe}_{3} \mathrm{O}_{4}, \mathrm{PC} @ I R 783-\mathrm{Fe}_{3} \mathrm{O}_{4}$, and GPC@IR783- $\mathrm{Fe}_{3} \mathrm{O}_{4} \mathrm{NPs}$ were determined by dynamic light scattering; (B) TEM images of IR783- $\mathrm{Fe}_{3} \mathrm{O}_{4}, \mathrm{PC} @ I R 783-\mathrm{Fe}_{3} \mathrm{O}_{4}$, and GPC@IR783- $\mathrm{Fe}_{3} \mathrm{O}_{4} \mathrm{NPs}$. The TEM images were enlarged and shown in inset images.

Abbreviations: PC, phosphatidylcholine; GPC, galactosyl conjugated pluronic $\mathrm{P}_{123}$ /phosphatidylcholine; TEM, transmission electron microscopy; NPs, nanoparticles.

weak signal was observed in RITC- $\mathrm{Fe}_{3} \mathrm{O}_{4}$ and PC@RITC$\mathrm{Fe}_{3} \mathrm{O}_{4}$, which might be because of nonspecific adsorption.

Furthermore, the cellular uptake of RITC-labeled $\mathrm{Fe}_{3} \mathrm{O}_{4}$ NPs by Huh-7 cells was examined over a period of $2 \mathrm{~h}$ by flow cytometry. Compared with RITC-Fe ${ }_{3} \mathrm{O}_{4} \mathrm{NPs}$, the cellular

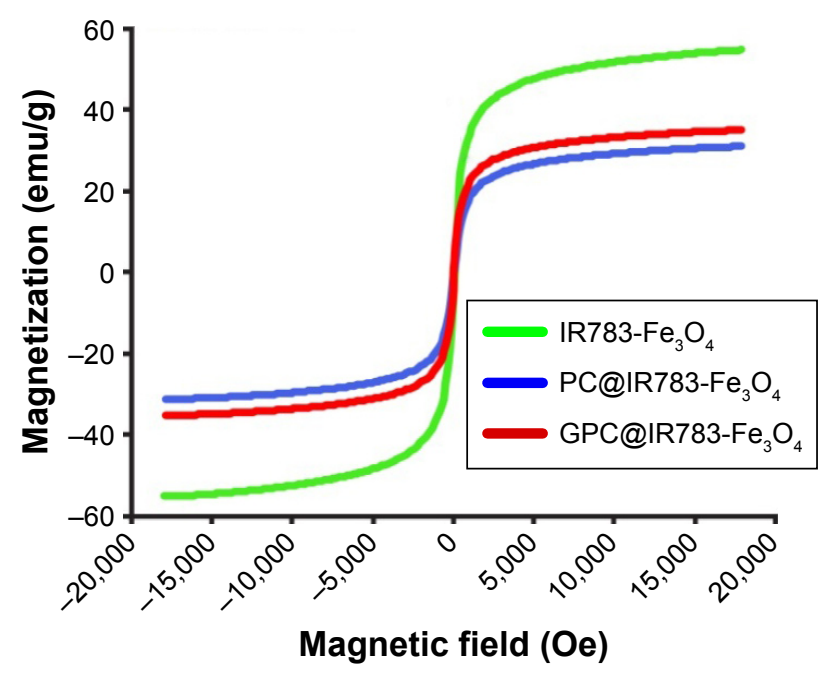

Figure 3 VSM magnetization curves of IR783- $\mathrm{Fe}_{3} \mathrm{O}_{4}, \mathrm{PC} @ I R 783-\mathrm{Fe}_{3} \mathrm{O}_{4}$, and GPC@ IR783- $-\mathrm{Fe}_{3} \mathrm{O}_{4} \mathrm{NPs}$.

Abbreviations: PC, phosphatidylcholine; GPC, galactosyl conjugated pluronic $\mathrm{P}_{123} /$ phosphatidylcholine; VSM, vibrating sample magnetometry; NPs, nanoparticles. uptake of PC@ $\mathrm{RITC}-\mathrm{Fe}_{3} \mathrm{O}_{4}$ and GPC@ $@$ RITC-Fe $\mathrm{O}_{4}$ NPs was enhanced 2.5-fold and 4.0-fold, respectively (Figure 4B). These results implied that the lipid layer might play an important role in increasing the affinity of lipid-coated NPs to the cell membrane, and therefore promoted cellular uptake through a mechanism described as contact-facilitated delivery. ${ }^{39}$ As it has been reported, ASGP receptors exhibit high affinity of Gal-modified NPs via receptor-mediated endocytosis. ${ }^{40}$ Results from the flow cytometry assay were consistent with those of the CLSM imaging assay (Figure S1), confirming that Gal- $\mathrm{P}_{123}$-conjugated $\mathrm{Fe}_{3} \mathrm{O}_{4}$ NPs displayed excellent specific uptake by Huh-7 cells.

\section{In vivo bio-fluorescence imaging and tumor targeting}

The real-time biodistribution and tumor-targeting efficiency of IR783- $\mathrm{Fe}_{3} \mathrm{O}_{4}$, PC@IR783- $\mathrm{Fe}_{3} \mathrm{O}_{4}$, and GPC@IR783- $\mathrm{Fe}_{3} \mathrm{O}_{4}$ administered intravenously into Huh-7 tumor-bearing nude mice were then visualized by a noninvasive near-infrared optical imaging technique at $1 \mathrm{~h}, 3 \mathrm{~h}$, and $6 \mathrm{~h}$ postinjection. After intravenous administration of IR783- $-\mathrm{Fe}_{3} \mathrm{O}_{4} \mathrm{NPs}$, a strong NIRF signal was detected in the liver within $3 \mathrm{~h}$ postinjection, indicating rapid distribution and clearance 

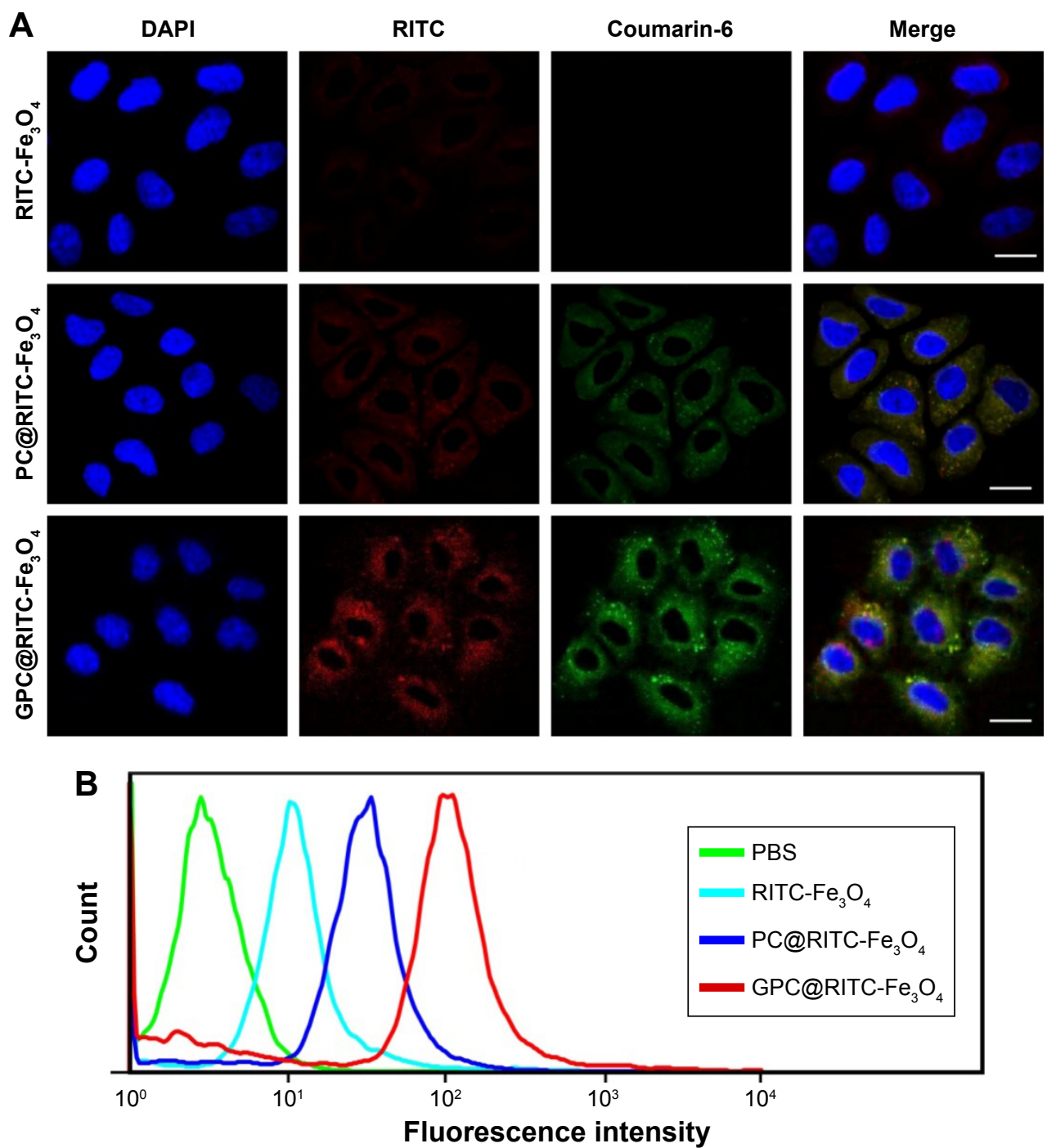

Figure 4 (A) CLSM images of Huh-7 with RITC-labeled $\mathrm{Fe}_{3} \mathrm{O}_{4} \mathrm{NPs}_{\text {(red: RITC-Fe }} \mathrm{O}_{4}$; green: Coumarin-6 labeled with lipid; blue: nuclei) Bar: $30 \mu$ m. (B) Flow cytometric analysis of RITC-Fe $\mathrm{O}_{4}, \mathrm{PC} @ \mathrm{RITC}-\mathrm{Fe}_{3} \mathrm{O}_{4}$, and GPC@RITC- $\mathrm{Fe}_{3} \mathrm{O}_{4} \mathrm{NPs}$ uptake by Huh-7 cells.

Abbreviations: PBS, phosphate buffer saline; RITC, rhodamine isothiocyanate; PC, phosphatidylcholine; GPC, galactosyl conjugated pluronic $\mathrm{P}_{123}$ /Phosphatidylcholine; CLSM, confocal laser scanning microscopy; NPs, nanoparticles.

of some NPs through hepatobiliary excretion. However, GPC@IR783- $\mathrm{Fe}_{3} \mathrm{O}_{4}$ exhibited stronger fluorescence intensity in tumor regions in quite a short time compared with other normal organs (Figure 5A). As time increased, GPC@ IR783- $-\mathrm{Fe}_{3} \mathrm{O}_{4}$ showed the highest uptake in tumor; 1.7-fold higher than PC@IR783- $\mathrm{Fe}_{3} \mathrm{O}_{4}$ and 6.1-fold higher than IR783- $-\mathrm{Fe}_{3} \mathrm{O}_{4}$. By comparison, the signal of PC@IR783- $\mathrm{Fe}_{3} \mathrm{O}_{4}$ showed no significant difference between tumor and normal liver tissues within $6 \mathrm{~h}$ postinjection (Figures $\mathrm{S} 2$ and 5B). The powerful tumor-targeting ability of GPC@IR783- $\mathrm{Fe}_{3} \mathrm{O}_{4}$ could be attributed to the specific affinity of Gal- $\mathrm{P}_{123}$ with ASGPR overexpressed by hepatocellular carcinoma cells. As reported previously, ASGPR is an integral membrane protein specifically expressed in hepatocytes and overexpressed in tumor hepatocytes. Especially in tumoral hepatocytes, this overexpressed receptor loses its polarized distribution and specifically binds terminal residues of galactose, allowing the Gal-modified polymer to target to these cells. ${ }^{40,41}$

\section{In vivo $M R I$ imaging application}

The distribution of GPC@IR783- $\mathrm{Fe}_{3} \mathrm{O}_{4}$ in mouse tumor tissues was also assessed by $\mathrm{T}_{2}$-weighted $\mathrm{MR}$ imaging. Sequential coronal images of $1 \mathrm{~mm}$ thickness were obtained before injection and $6 \mathrm{~h}$ after injection of three types of $\mathrm{Fe}_{3} \mathrm{O}_{4}$ NPs. Figure 6A illustrates that all NPs caused contrast enhancement in the tumor sites after intravenous administration. Moreover, the injection of GPC@IR783$\mathrm{Fe}_{3} \mathrm{O}_{4}$ resulted in higher MR contrast in the tumor sites 
A

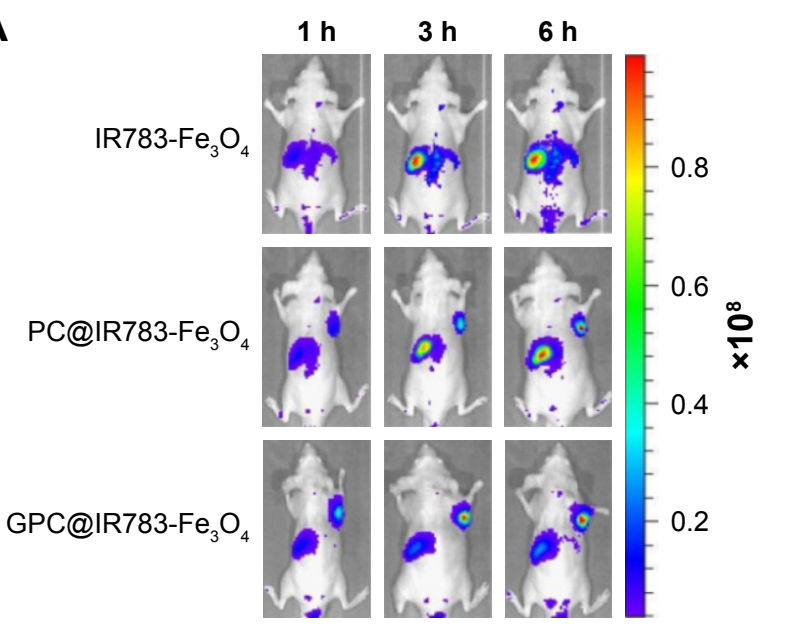

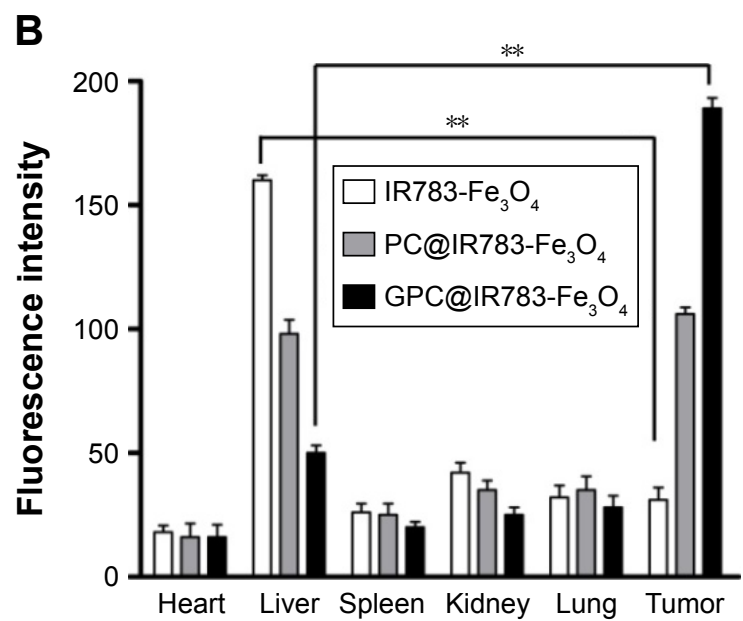

Figure 5 (A) In vivo bio-fluorescence imaging and tumor targeting of optical imaging technique at I h, $3 \mathrm{~h}$, and $6 \mathrm{~h}$ postinjection. (B) Biodistribution of IR783-labeled Fe $\mathrm{O}_{4}$ $\mathrm{NPs}$ in major organs excised from mice at $6 \mathrm{~h}$ postinjection (ANOVA, ${ }^{* * P}<0.0 \mathrm{I}$ vs IR783- $-\mathrm{Fe}_{3} \mathrm{O}_{4}$ ).

Abbreviations: PC, phosphatidylcholine; GPC, galactosyl conjugated pluronic $\mathrm{P}_{123}$ /phosphatidylcholine; ANOVA, one-way analysis of variance; NPs, nanoparticles.

than PC@IR783- $\mathrm{Fe}_{3} \mathrm{O}_{4}$ and IR783- $\mathrm{Fe}_{3} \mathrm{O}_{4}$, making for easy differentiation between cancer lesions and normal tissues in the MR images. $\mathrm{RSE}$ of $\mathrm{Fe}_{3} \mathrm{O}_{4} \mathrm{NPs}$ was calculated according to the SI of the defined tumor area, and the adjacent muscle is shown in Figure 6B. The RSE values of IR783- $\mathrm{Fe}_{3} \mathrm{O}_{4}$, PC@IR783- $\mathrm{Fe}_{3} \mathrm{O}_{4}$, and GPC@IR783- $\mathrm{Fe}_{3} \mathrm{O}_{4} 6 \mathrm{~h}$ after injection were $16.3 \%, 40.1 \%$, and $88.7 \%$, respectively. The use of GPC@IR783- $\mathrm{Fe}_{3} \mathrm{O}_{4}$ with ultrahigh $\mathrm{T}_{2}$ relaxivity as contrast agent may significantly improve the sensitivity of $\mathrm{T}_{2}$ imaging, which is vital for accurate detection and early diagnosis of cancer.

\section{In vitro and in vivo biocompatibility of GPC@IR783- $\mathrm{Fe}_{3} \mathrm{O}_{4} \mathrm{NPs}$}

It is necessary to ensure the biosafety of GPC@IR783- $\mathrm{Fe}_{3} \mathrm{O}_{4}$ NPs for their potential application in medical diagnosis and bio-imaging. We evaluated the cytotoxicity of IR783- $\mathrm{Fe}_{3} \mathrm{O}_{4}$, PC@IR783- $\mathrm{Fe}_{3} \mathrm{O}_{4}$, and GPC@IR783- $\mathrm{Fe}_{3} \mathrm{O}_{4}$ in LO2 cells by measuring cell viability via MTT assay. Figure 7A shows that the number of viable cells cultured with IR783- $\mathrm{Fe}_{3} \mathrm{O}_{4}, \mathrm{PC} @$ IR783- $\mathrm{Fe}_{3} \mathrm{O}_{4}$, and GPC@IR783- $\mathrm{Fe}_{3} \mathrm{O}_{4}$ was nearly the same as that of blank controls when the concentrations of Fe were 125 and $250 \mu \mathrm{g} / \mathrm{mL}$. And the number of viable cells was more
A

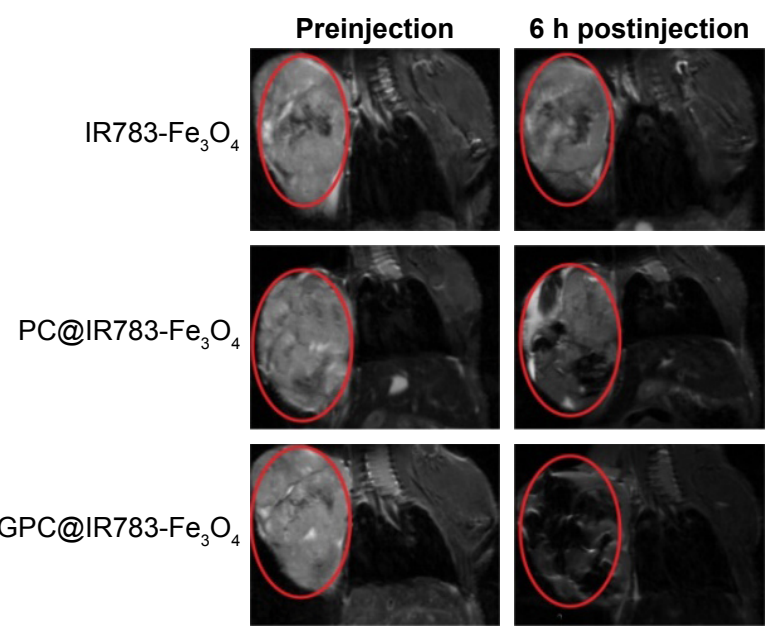

B

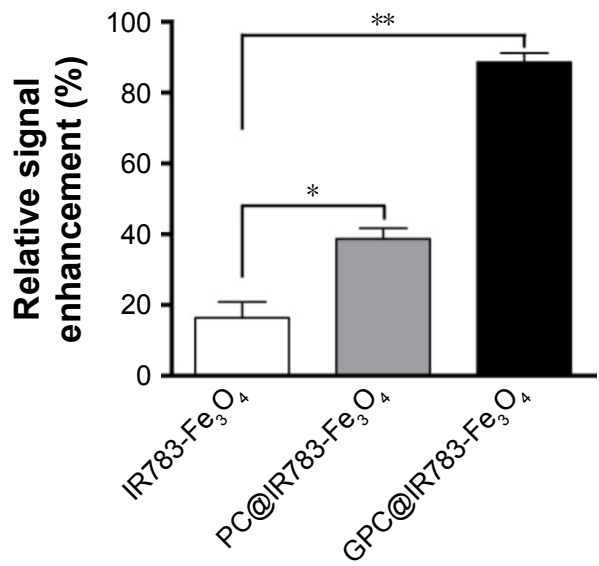

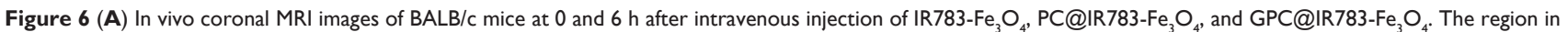
the red circle was xenograft tumor. (B) The relative signal enhancement of the xenograft tumor in T2 MR image (ANOVA, $* P<0.05$ and $* * P<0.01$ vs IR783-Fe $\mathrm{O}_{4}$ ).

Abbreviations: PC, phosphatidylcholine; GPC, galactosyl conjugated pluronic $\mathrm{P}_{123}$ /phosphatidylcholine; MRI, magnetic resonance imaging; ANOVA, one-way analysis of variance. 
A

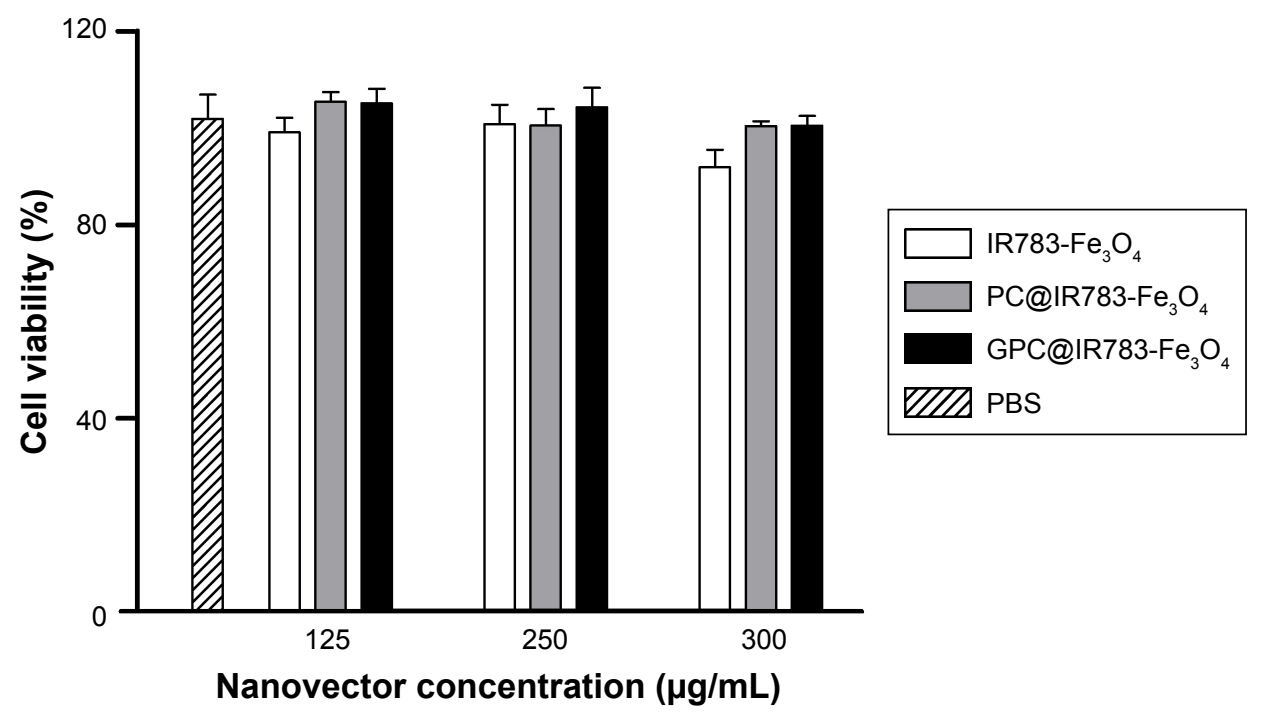

B
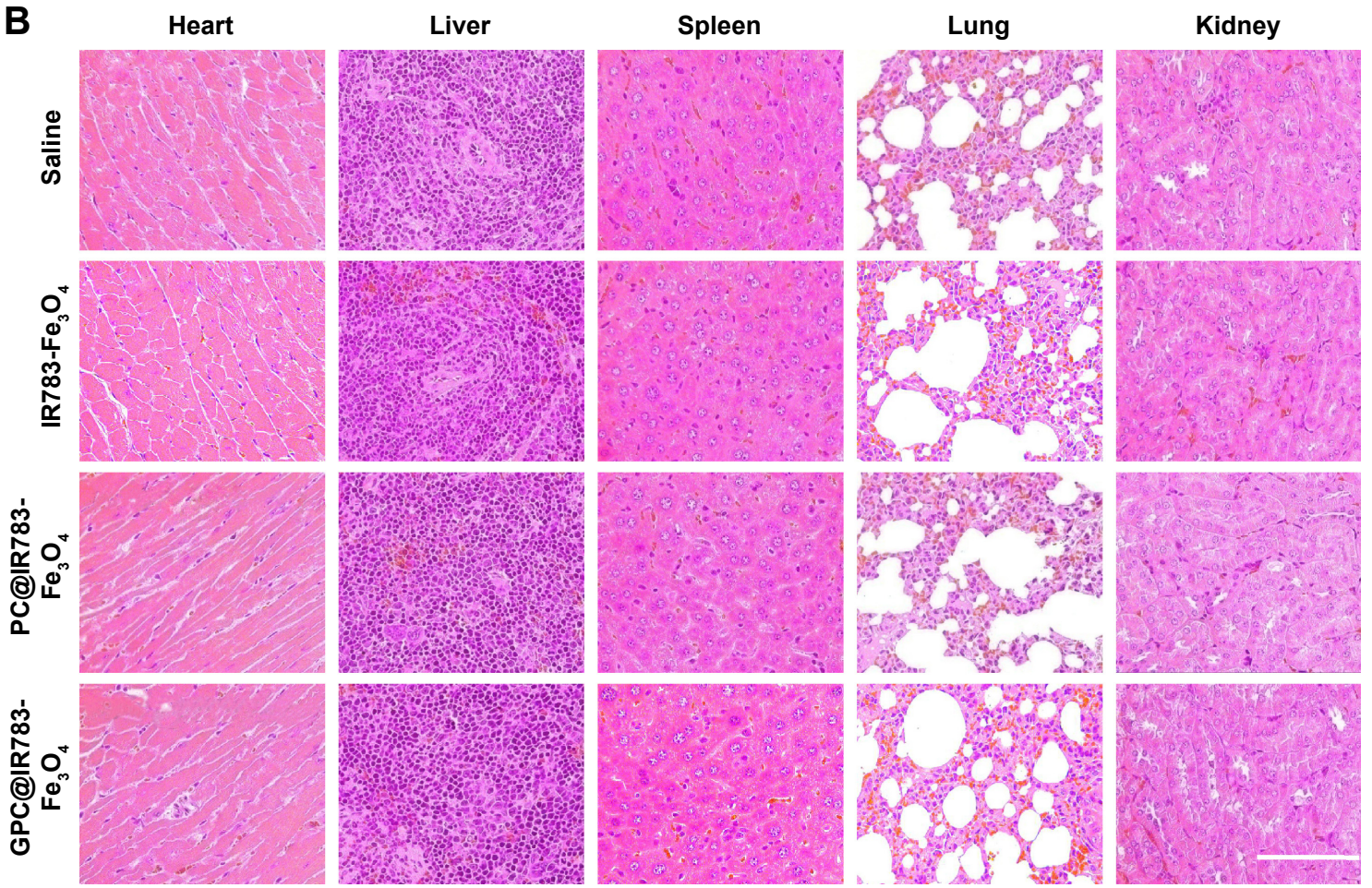

Figure 7 Biosafety evaluation of GPC@IR783- $\mathrm{Fe}_{3} \mathrm{O}_{4} \mathrm{NPs}$.

Notes: (A) MTT assay of LO2 cells incubated with GPC@IR783- $\mathrm{Fe}_{3} \mathrm{O}_{4}$ NPs at various concentrations for 48 h. Cells incubated with PBS were calculated as the control. (B) Histological examination of nude mice at 15 days after injection of $\mathrm{Fe}_{3} \mathrm{O}_{4} \mathrm{NPs}$. Their hearts, livers, spleens, lungs, and kidneys were stained by $\mathrm{H} \& \mathrm{E}$. Untreated healthy nude mice were examined as the control. Scale bar is $100 \mu \mathrm{m}$.

Abbreviations: PC, phosphatidylcholine; GPC, galactosyl conjugated pluronic $\mathrm{P}_{123}$ /phosphatidylcholine; MTT, 3-(4,5-Dimethylthiazol-2-yl)-2,5-diphenyltetrazolium bromide; PBS, phosphate buffer saline; H\&E, hematoxylin and eosin; NPs, nanoparticles.

than $90 \%$ even at a high concentration of $500 \mu \mathrm{g} / \mathrm{mL}$. These results demonstrated that GPC@IR783- $\mathrm{Fe}_{3} \mathrm{O}_{4}$ NPs possess excellent cell compatibility and low cytotoxicity. To further investigate the potential toxicity in vivo, GPC@IR783- $\mathrm{Fe}_{3} \mathrm{O}_{4}$ NPs were injected into the nude mice at a dose of $4 \mathrm{mg}$ Fe per $\mathrm{kg}$ of mouse body weight. For more than 15 days, these nude mice didn't behave abnormally compared with healthy nude mice without administration. Histological sections of their five major organs were stained with H\&E. No appreciable inflammatory response, cell degeneration, necrosis, or embolism was detected between the treated organs and the normal organs, proving that GPC@IR783- $\mathrm{Fe}_{3} \mathrm{O}_{4}$ caused no harm to the mice (Figure 7B). These results effectively provide evidence that GPC@IR783- $\mathrm{Fe}_{3} \mathrm{O}_{4}$ should be safe for biomedical imaging. 
The formed GPC@IR783- $\mathrm{Fe}_{3} \mathrm{O}_{4} \mathrm{NPs}$, with the combined appealing features of $\mathrm{Fe}_{3} \mathrm{O}_{4}$ and lipids, are biodegradable and do not seem to exert any appreciable in vivo toxicity. This can be confirmed by monitoring the physiological status of mice after intravenous treatment of NPs for at least 15 days. It should be mentioned that Gal- $\mathrm{P}_{123}$ modification of the particles rendered the NPs a slightly negative surface potential and good stability in physiological conditions. Furthermore, GPC@IR783- $\mathrm{Fe}_{3} \mathrm{O}_{4}$ showed specific affinity to ASGPR-overexpressing cancer cells in vitro and the xenografted tumor model in vivo, resulting in good tumor-targeting bio-fluorescence and MR imaging. Meanwhile, GPC@ IR783- $-\mathrm{Fe}_{3} \mathrm{O}_{4}$ escaped the uptake of the reticuloendothelial system, which may avoid the unspecific distribution. With the higher and noncompromised MR imaging sensitivity, the designed NPs should be able to be used for sensitive fluorescence and MR imaging.

\section{Conclusion}

Hepatocellular carcinoma cell-targeting fluorescence/MR dual-modality imaging NPs were successfully prepared through a convenient process. Synergistic interaction of the coated Gal- $\mathrm{P}_{123}$ surface and embedded IR783- $-\mathrm{Fe}_{3} \mathrm{O}_{4}$ is vital for GPC@IR783- $\mathrm{Fe}_{3} \mathrm{O}_{4}$ to achieve good fluorescence/MR performance as well as outstanding biocompatibility. We demonstrated that large payloads of cargo (contrast agents) were delivered to xenograft tumor by targeting ASGPR overexpressed tumoral hepatocytes in vivo. These studies suggest that GPC@IR783- $\mathrm{Fe}_{3} \mathrm{O}_{4}$ NPs have considerable potential for further development as efficient dual-modality contrast agents for practical biomedical application.

\section{Acknowledgments}

We are grateful for the financial support obtained from the National Natural Science Foundation of China (81571796), the Youth Innovation Promotion Association (2015229), and the SA-SIBS Scholarship Program. We also thank Prof Peng Zhang's Research Group in Shanghai Jiao Tong University for the supply of $\mathrm{Fe}_{3} \mathrm{O}_{4} \mathrm{NPs}$, and Prof Jianping Zhang in Fudan University Shanghai Cancer Center for his assistance with MRI measurements and helpful discussions.

\section{Disclosure}

The authors report no conflicts of interest in this work.

\section{References}

1. Ferlay J, Soerjomataram I, Dikshit R, et al. Cancer incidence and mortality worldwide: sources, methods and major patterns in GLOBOCAN 2012. Int J Cancer. 2015;136(5):E359-E386.
2. Shiraha H, Yamamoto K, Namba M. Human hepatocyte carcinogenesis (review). Int J Oncol. 2013;42(4):1133-1138.

3. Torre LA, Bray F, Siegel RL, Ferlay J, Lortet-Tieulent J, Jemal A. Global cancer statistics, 2012. CA Cancer J Clin. 2015;65(2):87-108.

4. Waghray A, Murali AR, Menon KN. Hepatocellular carcinoma: from diagnosis to treatment. World J Hepatol. 2015;7(8):1020-1029.

5. Dong Y, Wang WP, Mao F, Ji ZB, Huang BJ. Application of imaging fusion combining contrast-enhanced ultrasound and magnetic resonance imaging in detection of hepatic cellular carcinomas undetectable by conventional ultrasound. J Gastroenterol Hepatol. 2016;31(4): 822-828.

6. Kunishi Y, Numata K, Morimoto M, et al. Efficacy of fusion imaging combining sonography and hepatobiliary phase MRI with Gd-EOBDTPA to detect small hepatocellular carcinoma. AJR Am J Roentgenol. 2012;198(1):106-114.

7. Wang R, Luo Y, Yang S, et al. Hyaluronic acid-modified manganesechelated dendrimer-entrapped gold nanoparticles for the targeted CT/MR dual-mode imaging of hepatocellular carcinoma. Sci Rep. 2016; 6:33844.

8. Ronot M, Clift AK, Vilgrain V, Frilling A. Functional imaging in liver tumours. J Hepatol. 2016;65(5):1017-1030.

9. Wang J, Zhao H, Zhou Z, et al. MR/SPECT imaging guided photothermal therapy of tumor-targeting Fe@Fe3O4 nanoparticles in vivo with low mononuclear phagocyte uptake. ACS Appl Mat Interfaces. 2016; 8(31):19872-19882.

10. Wei Z, Wu Y, Zhao Y, et al. Multifunctional nanoprobe for cancer cell targeting and simultaneous fluorescence/magnetic resonance imaging. Anal Chim Acta. 2016;938:156-164.

11. Situ JQ, Wang XJ, Zhu XL, et al. Multifunctional SPIO/DOX-loaded A54 homing peptide functionalized dextran-g-PLGA micelles for tumor therapy and MR imaging. Sci Rep. 2016;6:35910.

12. Shanavas A, Sasidharan S, Bahadur D, Srivastava R. Magnetic coreshell hybrid nanoparticles for receptor targeted anti-cancer therapy and magnetic resonance imaging. J Colloid Interface Sci. 2017;486: $112-120$.

13. Park JO, Stephen Z, Sun C, et al. Glypican-3 targeting of liver cancer cells using multifunctional nanoparticles. Mol Imaging. 2011; 10(1):69-77.

14. Shen Z, Wu A, Chen X. Iron oxide nanoparticle based contrast agents for magnetic resonance imaging. Mol Pharm. Epub 2016.

15. Lu ZR, Mohs AM, Zong Y, Feng Y. Polydisulfide Gd(III) chelates as biodegradable macromolecular magnetic resonance imaging contrast agents. Int J Nanomedicine. 2006;1(1):31-40.

16. Yuan Y, Ding Z, Qian J, et al. Casp3/7-Instructed Intracellular aggregation of Fe3o4 nanoparticles enhances T2 MR imaging of tumor apoptosis. Nano Lett. 2016;16(4):2686-2691.

17. Toy R, Bauer L, Hoimes C, Ghaghada KB, Karathanasis E. Targeted nanotechnology for cancer imaging. Adv Drug Deliv Rev. 2014;76: 79-97.

18. De M, Chou SS, Joshi HM, Dravid VP. Hybrid magnetic nanostructures (MNS) for magnetic resonance imaging applications. Adv Drug Deliv Rev. 2011;63(14-15):1282-1299.

19. Ma Y, Tong S, Bao G, Gao C, Dai Z. Indocyanine green loaded SPIO nanoparticles with phospholipid-PEG coating for dual-modal imaging and photothermal therapy. Biomaterials. 2013;34(31): 7706-7714.

20. Tang Y, Zhang C, Wang J, et al. MRI/SPECT/Fluorescent tri-modal probe for evaluating the homing and therapeutic efficacy of transplanted mesenchymal stem cells in a rat ischemic stroke model. Adv Funct Mater. 2015;25(7):1024-1034.

21. Wei KC, Lin FW, Huang CY, et al. 1,3-Bis(2-chloroethyl)-1-nitrosourealoaded bovine serum albumin nanoparticles with dual magnetic resonance-fluorescence imaging for tracking of chemotherapeutic agents. Int J Nanomedicine. 2016;11:4065-4075.

22. Wang G, Gao W, Zhang X, Mei X. Au nanocage functionalized with ultra-small Fe3O4 nanoparticles for targeting T1-T2 Dual MRI and CT imaging of tumor. Sci Rep. 2016;6:28258. 
23. Zhao HY, Liu S, He J, et al. Synthesis and application of strawberry-like Fe3O4-Au nanoparticles as CT-MR dual-modality contrast agents in accurate detection of the progressive liver disease. Biomaterials. 2015; 51:194-207.

24. Li J, Hu Y, Yang J, et al. Hyaluronic acid-modified Fe3O4@Au core/ shell nanostars for multimodal imaging and photothermal therapy of tumors. Biomaterials. 2015;38:10-21.

25. Lee DH, Lee JM. Whole-body PET/MRI for colorectal cancer staging: Is it the way forward? J Magn Reson Imaging. 2017;45(1):25-35.

26. Goh V, Prezzi D, Mallia A, et al. Positron emission tomography/ magnetic resonance imaging of gastrointestinal cancers. Semin Ultrasound CT MR. 2016;37(4):352-357.

27. He X, Gao J, Gambhir SS, Cheng Z. Near-infrared fluorescent nanoprobes for cancer molecular imaging: status and challenges. Trends Mol Med. 2010;16(12):574-583.

28. Kovar JL, Simpson MA, Schutz-Geschwender A, Olive DM. A systematic approach to the development of fluorescent contrast agents for optical imaging of mouse cancer models. Anal Biochem. 2007; 367(1):1-12.

29. Zhou Z, Chen H, Lipowska M, et al. A dual-modal magnetic nanoparticle probe for preoperative and intraoperative mapping of sentinel lymph nodes by magnetic resonance and near infrared fluorescence imaging. J Biomat Appl. 2013;28(1):100-111.

30. Wang Y, Chen J, Yang B, et al. In vivo MR and fluorescence dual-modality imaging of atherosclerosis characteristics in mice using Profilin-1 targeted magnetic nanoparticles. Theranostics. 2016;6(2): 272-286.

31. Zeng L, Luo L, Pan Y, Luo S, Lu G, Wu A. In vivo targeted magnetic resonance imaging and visualized photodynamic therapy in deep-tissue cancers using folic acid-functionalized superparamagnetic-upconversion nanocomposites. Nanoscale. 2015;7(19):8946-8954.

32. Xue WJ, Feng Y, Wang F, et al. Asialoglycoprotein receptor-magnetic dual targeting nanoparticles for delivery of RASSF1A to hepatocellular carcinoma. Sci Rep. 2016;6:22149.
33. Zhang X, Guo S, Fan R, et al. Dual-functional liposome for tumor targeting and overcoming multidrug resistance in hepatocellular carcinoma cells. Biomaterials. 2012;33(29):7103-7114.

34. Chen Y, Wang Q, Wang T. Facile large-scale synthesis of brain-like mesoporous silica nanocomposites via a selective etching process. Nanoscale. 2015;7(39):16442-16450.

35. Jiang L, Zhou Q, Mu K, et al. pH/temperature sensitive magnetic nanogels conjugated with Cy5.5-labled lactoferrin for MR and fluorescence imaging of glioma in rats. Biomaterials. 2013;34(30):7418-7428.

36. Luo B, Wang S, Rao R, et al. Conjugation magnetic PAEEP-PLLA nanoparticles with lactoferrin as a specific targeting MRI contrast agent for detection of brain glioma in rats. Nanoscale Res Lett. 2016; 11(1):227.

37. Semkina A, Abakumov M, Grinenko N, et al. Core-shell-corona doxorubicin-loaded superparamagnetic Fe3O4 nanoparticles for cancer theranostics. Colloids Surf B Biointerfaces. 2015;136:1073-1080.

38. Zhang W, Li X, Zou R, et al. Multifunctional glucose biosensors from $\mathrm{Fe}_{3} \mathrm{O}_{4}$ nanoparticles modified chitosan/graphene nanocomposites. Sci Rep. 2015;5:11129.

39. Liu J, Stace-Naughton A, Jiang X, Brinker CJ. Porous nanoparticle supported lipid bilayers (protocells) as delivery vehicles. J Am Chem Soc. 2009;131(4):1354-1355.

40. Khorev O, Stokmaier D, Schwardt O, Cutting B, Ernst B. Trivalent, $\mathrm{Gal} / \mathrm{GalNAc}$-containing ligands designed for the asialoglycoprotein receptor. Bioorg Med Chem. 2008;16(9):5216-5231.

41. Trere D, Fiume L, De Giorgi LB, Di Stefano G, Migaldi M, Derenzini M. The asialoglycoprotein receptor in human hepatocellular carcinomas: its expression on proliferating cells. Br J Cancer. 1999;81(3): 404-408. 


\section{Supplementary materials}

Cellular uptake of GPC@RITC- $\mathrm{Fe}_{3} \mathrm{O}_{4}$ in different cells

Huh-7 cells $\left(1 \times 10^{5}\right.$ cells per well) and LO2 cells were seeded in 24 -well plates and cultured at $37^{\circ} \mathrm{C}$ for $24 \mathrm{~h}$. The medium was replaced with fresh medium; meanwhile, GPC@ RITC-Fe ${ }_{3} \mathrm{O}_{4}(100 \mu \mathrm{g} / \mathrm{mL}$ Fe/well $)$ was added in the culture medium and incubated for $2 \mathrm{~h}$ at $37^{\circ} \mathrm{C}$. Next, the cells were washed three times with ice-cold PBS and fixed with 4\% paraformaldehyde for $15 \mathrm{~min}$, followed by washing with PBS three times. The nuclei were stained with 4',6-diamidino2-phenylindole for $10 \mathrm{~min}$ and observed by CLSM.

Flow cytometry was also used to evaluate the cellular uptake of GPC@RITC-Fe $\mathrm{O}_{4}(100 \mu \mathrm{g} / \mathrm{mL}$ Fe/well) in the aforementioned two cell lines. Huh-7 cells and LO2 cells were seeded at $1 \times 10^{5}$ cells per well for $24 \mathrm{~h}$ at $37^{\circ} \mathrm{C}$ prior to the study. Cells were then incubated in medium containing
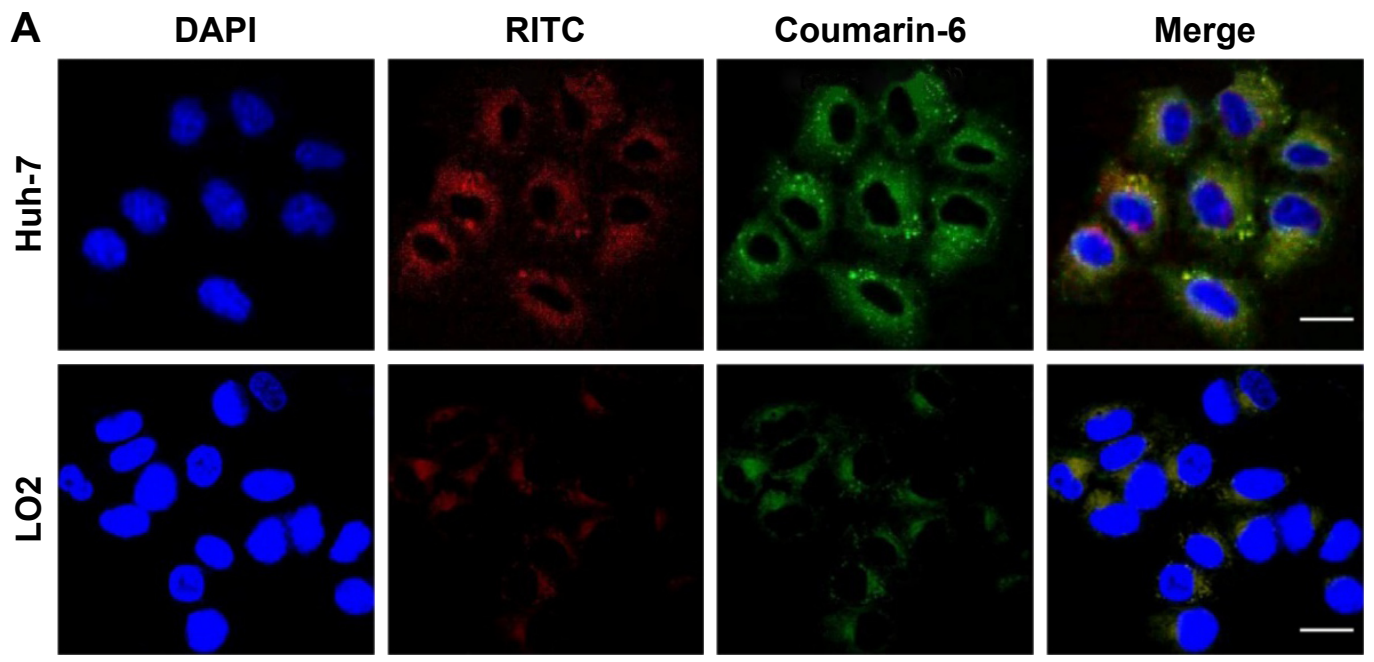

B

Huh-7
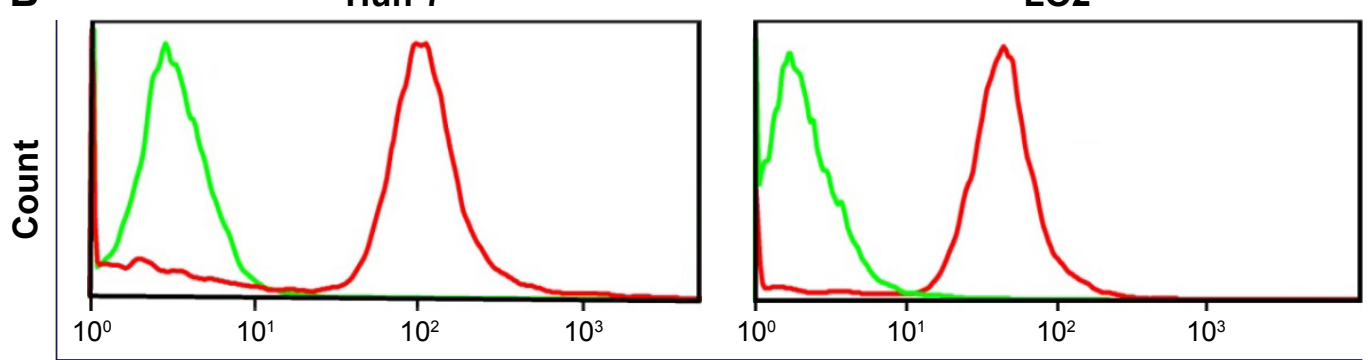

Fluorescence intensity

PBS - GPC@RITC-Fe $\mathrm{O}_{4}$

Figure SI (A) CLSM images of GPC@RITC-Fe $\mathrm{O}_{4}$ NPs incubated with Huh-7 cells and LO2 cells (red: RITC-Fe $\mathrm{O}_{4}$; green: Coumarin-6 labeled in lipid; blue: nuclei) Bar: $30 \mu \mathrm{m}$. (B) Flow cytometric analysis of GPC@RITC-Fe $\mathrm{O}_{4} \mathrm{NPs}$ uptake by Huh-7 cells and LO2 cells.

Abbreviations: RITC, rhodamine isothiocyanate; GPC, galactosyl conjugated pluronic $\mathrm{P}_{123}$ /phosphatidylcholine; CLSM, confocal laser scanning microscopy; $\mathrm{NPs}$, nanoparticles; PBS, phosphate-buffered saline.

Table SI Average size of three types of $\mathrm{Fe}_{3} \mathrm{O}_{4}$ NPs during storage $(n=3)$

\begin{tabular}{|c|c|c|c|c|}
\hline \multirow{2}{*}{$\begin{array}{l}\mathrm{Fe}_{3} \mathrm{O}_{4} \text { nanoparticles/ } \\
\text { average size }(\mathrm{nm})\end{array}$} & \multicolumn{4}{|c|}{ Storage time (d) } \\
\hline & I & 7 & 15 & 30 \\
\hline IR783- $\mathrm{Fe}_{3} \mathrm{O}_{4}$ & $70.92 \pm 2.76$ & $83.19 \pm 1.82$ & $98.13 \pm 2.55$ & $116.21 \pm 2.59$ \\
\hline PC@IR783- $\mathrm{Fe}_{3} \mathrm{O}_{4}$ & $81.92 \pm 1.86$ & $81.96 \pm 2.71$ & $81.96 \pm 1.9$ & $82.02 \pm 2.36$ \\
\hline GPC@IR783- $\mathrm{Fe}_{3} \mathrm{O}_{4}$ & $83.2 \pm 2.64$ & $83.18 \pm 2.81$ & $83.21 \pm 1.75$ & $83.26 \pm 2.97$ \\
\hline
\end{tabular}

Notes: Mean $\pm \mathrm{SD} ; \mathrm{n}=3$.

Abbreviations: PC, phosphatidylcholine; GPC, galactosyl conjugated pluronic $\mathrm{P}_{123}$ /phosphatidylcholine; SD, standard deviation; NPs, nanoparticles. 


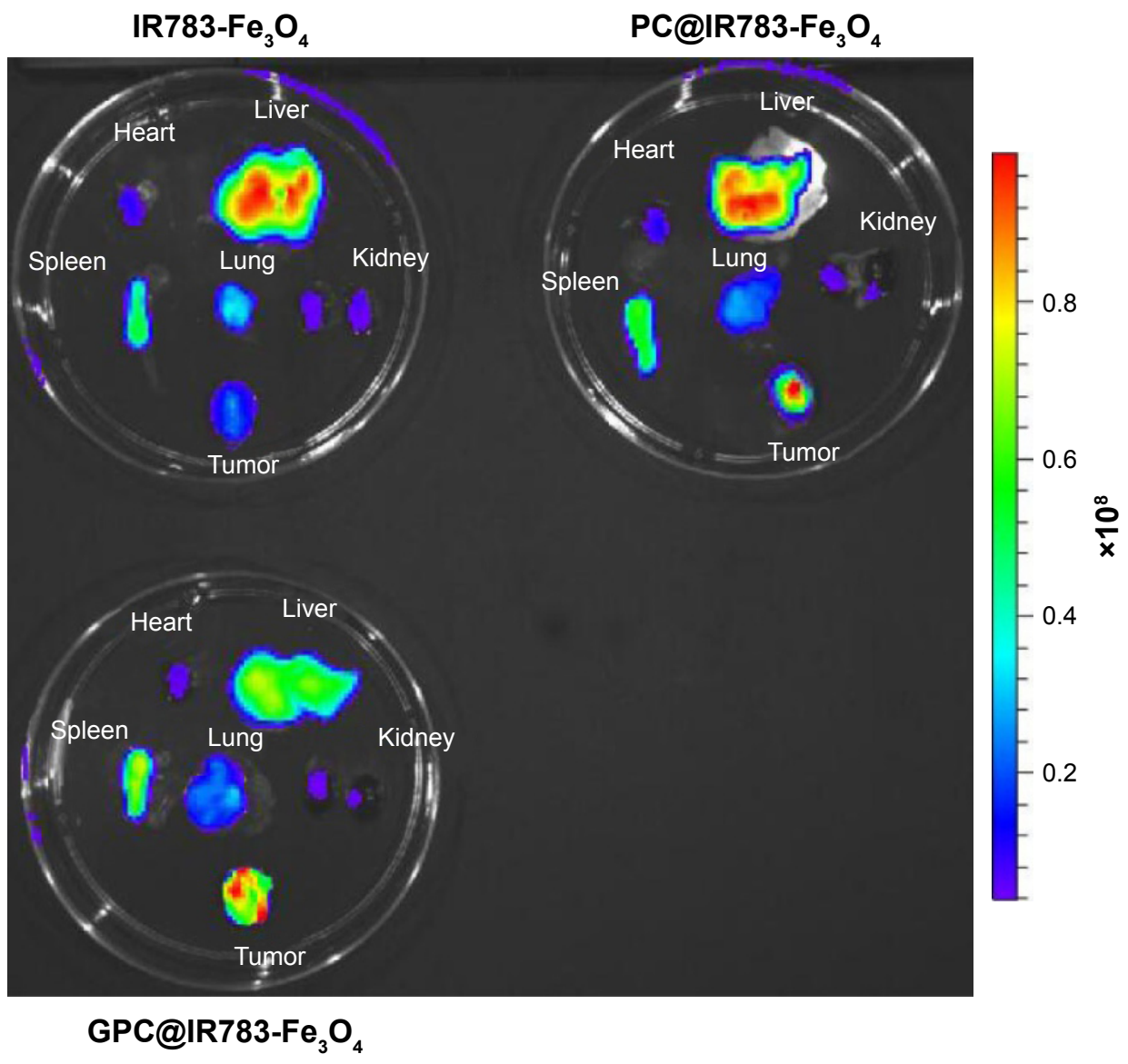

Figure S2 Fluorescence images of organs excised at $6 \mathrm{~h}$ postinjection.

Abbreviations: PC, phosphatidylcholine; GPC, galactosyl conjugated pluronic $\mathrm{P}_{123} /$ phosphatidylcholine.

GPC@RITC- $\mathrm{Fe}_{3} \mathrm{O}_{4}$. After $2 \mathrm{~h}$ of incubation, cells were washed with PBS three times, harvested by trypsinization, and collected in PBS to quantify fluorescent signals of RITC.

\section{In vivo bio-fluorescence imaging and tumor targeting}

Tumor-bearing mice were injected via the tail vein at a dose of $2 \mathrm{mg} \mathrm{Fe} \mathrm{per} \mathrm{kg} \mathrm{of} \mathrm{mouse} \mathrm{body} \mathrm{weight.} \mathrm{Tumors} \mathrm{as} \mathrm{well}$ as internal organs (heart, liver, spleen, lung, and kidney) were removed at $6 \mathrm{~h}$ postinjection and analyzed directly on the fluorescent imager. Visualization was observed at excitation of $730 \mathrm{~nm}$ and emission of $790 \mathrm{~nm}$. Living Image software was used to calculate the fluorescence intensity of the organs.

\section{Publish your work in this journal}

The International Journal of Nanomedicine is an international, peerreviewed journal focusing on the application of nanotechnology in diagnostics, therapeutics, and drug delivery systems throughout the biomedical field. This journal is indexed on PubMed Central, MedLine, CAS, SciSearch ${ }^{\circledR}$, Current Contents $₫ /$ Clinical Medicine,
Journal Citation Reports/Science Edition, EMBase, Scopus and the Elsevier Bibliographic databases. The manuscript management system is completely online and includes a very quick and fair peer-review system, which is all easy to use. Visit http://www.dovepress.com/ testimonials.php to read real quotes from published authors. 